\title{
Effects of Coping Strategies on Language Anxiety of Japanese EFL Learners: Investigating Willingness to Communicate
}

\author{
Toshinori Yasuda \\ Waseda University, Tokyo, Japan \\ Lisa Nabei \\ Tokai University, Tokyo, Japan
}

\begin{abstract}
While several studies have discovered authentic coping strategies for language anxiety that learners use in actual classroom situations, their effects in terms of anxiety reduction remains unclear. This study investigates the effects of coping strategies on the levels of classroom speaking anxiety among Japanese EFL learners, focusing on five coping strategies extracted by previous research (preparation, relaxation, positive thinking, peer seeking, and resignation). Incidentally, general statistical methods such as correlation and regression analyses should be cautiously used for those two specific constructs (coping strategy and language anxiety), because the difficulty in distinguishing the following two directions (entitled $A$ and $B$ ) in one dataset could distort the results: (A) because learners feel more (or less) anxious, they need to use coping strategies more (or less) frequently; (B) because learners use coping strategies more (or less) frequently they feel less (or more) anxious. Therefore, the present study employs "willingness to communicate" as an alternative variable and exploits these statistical approaches to investigate the effects of the coping strategies. The analysis of 149 Japanese EFL learners indicated that preparation and positive thinking were significantly effective strategies for coping with speaking anxiety among the group, both of which are discussed in terms of more general perspectives. The pedagogical implications describe teachers' responsibilities to enable learners to use these two coping strategies more effectively.
\end{abstract}

Index Terms - language anxiety, coping strategy, willingness to communicate, speaking activity, Japanese EFL learners

\section{INTRODUCTION AND LITERATURE REVIEW}

\section{A. Language Anxiety}

Language anxiety has long been actively researched as a critical individual difference, the characteristics of which could be described in terms of two major perspectives. First, language anxiety is essentially a transient and moment-to-moment emotion experienced mainly in second or foreign language (L2 or FL) learning and use. Horwitz, Horwitz, and Cope (1986) defined it as "a distinct complex of self-perceptions, beliefs, feelings, and behaviors related to classroom language learning arising from the uniqueness of the language learning process" (p. 128), and MacIntyre (1999) refers to "the worry and negative emotional reaction aroused when learning or using a second language" (p. 27). Thus, language anxiety should be distinguished from trait anxiety which is conceptualized as a personality characteristic that indicates the extent to which a person can be anxious (Horwitz, 2001).

Second, language anxiety has various negative impacts on a broad spectrum of L2 or FL learning and performance. MacIntyre and Gardner (1994), who recruited undergraduate learners of French at a university in Canada, concluded that language anxiety could affect a wide range of cognitive processes including input, processing, and output. Although earlier studies had generally associated language anxiety with speaking and listening (Horwitz, 2010), Hilleson's (1996) qualitative study pointed out that it had negative influences on all four language skills including reading and writing. Saito and Samimy (1996) investigated the relationships between language anxiety and the final grade in three levels of Japanese courses and concluded that language anxiety had negative impacts particularly in intermediate and advanced courses. This result indicates that language anxiety might have an impact regardless of learners' proficiency levels. Kim's (1998) correlation analysis for college students in Korea found that learners with high language anxiety tended to avoid working hard in the traditional FL learning setting. For example, they were likely to elicit help from others for their homework as they considered English learning to be a waste of time. Although some recent studies have shed light on the positive aspects of language anxiety (e.g., Dewaele \& MacIntyre, 2014), those negative influences are still dominant in the field of language learning.

As mentioned above, language anxiety, which has various negative impacts, is state anxiety experienced as a transient emotion specifically in L2 or FL learning and performance. Thus, the question of how to reduce language anxiety has also been well-researched (Dörnyei, 2005). Previous research has focused generally on dedicated ways of 
combating anxiety that language learners experience particularly in L2 or FL learning situations. One of the major achievements is teachers' class management to control anxiety. Young's (1999) comprehensive work discusses how to cope with language anxiety in various situations including reading, writing, listening, and speaking. Additionally, the Community Language Learning was developed based on a belief that teachers should deal with the fear that most adult learners often experience in learning situations. In this method, teachers usually focus on helping students overcome negative feelings including anxiety that might impede their L2 learning (Larsen-Freeman, 2000). Moreover, in a recent publication, Alrabai (2015) found that teachers' anxiety-reducing strategies such as "allowing students to practice self-talk before they talk in real situations in the classroom" and "avoiding putting individual students 'on the spot' when correcting their errors" could successfully reduce learners' communication apprehension and fear of negative evaluation. As stated in those studies, the teachers' role has long been emphasized in alleviating language anxiety.

\section{B. Coping Strategies for Language Anxiety}

Although teachers' responsibilities in language classroom are important, learner autonomy has been one of the most focused scopes in L2 or FL learning with the prevalence of the learner-centered approach. Although it is still difficult to define exactly the concept of autonomy, some degree of consensus shows that it includes various dimensions such as behavioral, cognitive, affective, social, and political aspects (Benson, 1997; Murase, 2015; Oxford, 2003). Thus, from this perspective, while teachers' efforts to create a low-anxiety atmosphere are critical, language learners, as well as teachers, are also required to control their own emotional aspects including language anxiety. More specifically, learners should make efforts to use some coping strategies for controlling their own language anxiety.

There are two viewpoints to be considered in the discussion of coping strategies for language anxiety. First, academic research should focus on realistic coping strategies which learners could use in actual learning situations. As language anxiety is a situation-specific concept, learners should employ each unique coping strategy in each respective situation. For example, in the case of immigrant children who study with native speaker classmates in English as a Second Language (ESL) setting, they would feel greater fear of negative evaluation from classmates than from teachers. On the other hand, in the case of students who learn in an English as a Foreign Language (EFL) setting with peers at a similar level, they would pay more attention to evaluation from teachers rather than from classmates. Further, because an English class includes extremely dynamic processes with a flurry of various information and interactions, learners have a clear need for coping strategies that they can use immediately in each particular moment. For these reasons, academic research should employ coping strategies which can be used practically by target language learners in real situations. The second issue is the lack of empirical evidence for the effects of coping strategies. Regardless of how many coping strategies actual learners are using, it is still ambiguous whether they should be encouraged to use those strategies unless their effects become clear.

While some, but not many, previous studies have made efforts to discover realistic coping strategies that learners are making actual use of in learning situations, there are, unfortunately, very few findings on the true effects of those strategies. Pappamihiel (2002) explored Mexican-born middle school students enrolled in ESL programs in the U.S. to find that they used such coping strategies as avoidance (e.g., not speaking in class), using friends as intermediaries in class (e.g., asking friends to speak out the answer in English), and pretending that there was no one else around. Although the most common coping strategy in this study was avoidance, it might not be regarded as an optimal strategy since learners' active engagement with English learning would be impeded. Kondo and Yang (2004) inductively extracted coping strategies that Japanese EFL learners make real use of in classroom situations. A group of 202 undergraduate learners responded to a questionnaire measuring language anxiety and then recorded their own coping strategies for language anxiety which they had used from junior high school age up until the present day. The results extracted 70 strategies which were summarized into 5 categories: preparation (e.g., I prepare myself better; I check my dictionary), relaxation (e.g., I try to calm down; I take a deep breath), positive thinking (e.g., I try to be confident; I tell myself that I am OK), peer seeking (e.g., I tell myself that the others must also be anxious), and resignation (e.g., I give up; I stop paying attention). However, this study did not clearly indicate the effects of those strategies in reducing language anxiety.

\section{Methodological Issues in Investigating Effects of Coping Strategies}

As explained, one of the major current issues is the lack of empirical evidence for the effects of coping strategies. However, in fact, there are some methodological difficulties in conducting the academic research required. One of the most direct approaches is a longitudinal study. In this case, the research should be designed to include a training session to encourage learners to use coping strategies and observe their strategy use for a certain period. The research would conduct a pre- and post-test to ascertain the level of change in language anxiety. As a longitudinal study would easily incur a great deal of labor, a one-shot study should be conducted in advance to anticipate the effects of coping strategies before commencing the longitudinal process. However, the one-shot study still presents some methodological issues.

In the most direct method of one-shot research, participants using particular coping strategies would be required to answer a questionnaire which examines the effects of the strategies on a simple scale. For example, learners might answer the question "how effectively does your coping strategy reduce your language anxiety in classroom?" using the simple scale of " 1 = fully ineffective to 5 = fully effective." However, since language anxiety is an intangible psychological concept, academic research should adopt as reliable and valid questionnaires as possible to investigate the 
change of language anxiety (i.e. the effects of coping strategies). For example, Horwitz, Horwitz, and Cope (1986) introduced the Foreign Language Classroom Anxiety Scale (FLCAS), one of the most frequently-used questionnaires around the world, and Dewaele and MacIntyre (2014) revised it to create a shorter version. Unless research employs these valid questionnaires, as opposed to merely recording the effects in a simple scale mentioned above, results will remain unclear even if the effects of coping strategies are calculated quantitatively.

Therefore, the one-shot study with appropriate measurement scales is the first step toward the subsequent research. The most general method in this perspective is to analyze statistically the relationships between language anxiety and coping strategies. There are existing scales to measure language anxiety such as Horwitz et al. (1986) and Dewaele and MacIntyre (2014) which include, for example, the question items of "I start to panic when I have to speak without preparation in language class" and "I often feel like not going to my language class." On another front, there are only a few instruments to measure the frequency of coping strategy use. Marwan (2007) developed a measurement scale based on the results of Kondo and Yang (2004), which includes 15 items such as "I try to make a habit of studying English everyday" and "I try to relax when I am in my English class." According to many previous studies for language learners' psychology, the academic research would generally measure language anxiety and coping strategies by using each questionnaire scale and subsequently employ correlation analysis and regression analysis with coping strategies as predictor variables and language anxiety as an outcome variable.

However, particularly regarding the relationships between language anxiety and coping strategies, those methodologies would cause some issues in terms of directionality. To be more specific, it is difficult to distinguish the mixture of the directions (A) and (B) which occur when learners respond to question items. If correlation and regression analyses are conducted when those two directions are in one dataset, the results would be seriously damaged as stated below.

(A) Because learners feel more (or less) anxious, they need to use coping strategies more (or less) frequently.

(B) Because learners use coping strategies more (or less) frequently, they feel less (or more) anxious.

The directions (A) and (B) would be paraphrased as below with actual measurement items:

(A) Because I start to panic when I have to speak without preparation in language class (high score on language anxiety), I try to make a habit of studying English everyday (high score on coping strategies).

(B) Because I try to make a habit of studying English everyday (high score on coping strategies), I do not start to panic when I have to speak without preparation in language class (low score on language anxiety).

There are two serious potential problems in this directionality issue. First, due to the mixture of (A) and (B), it still remains unclear which one (i.e., language anxiety or coping strategies) becomes a predictor or an outcome variable. Thus, as academic studies cannot use regression analysis, they should use correlation analysis instead. Second, considering the correlation coefficient between language anxiety and coping strategies, while the case (A) would show positive correlation because the more learners feel anxious, the more frequently they use coping strategies, the case (B) would indicate negative correlation because the more frequently learners use coping strategies, the less anxious they feel. When those two types of correlations are in only one dataset, the result would be severely distorted. More specifically, it might show no significant correlations due to the mixture of the positive and negative correlations. For those two reasons, the most serious issue here is that correlational and regression analysis would not appropriately reflect the effects of coping strategies on language anxiety.

\section{Willingness to Communicate as an Alternative Variable}

One of the substitute methodologies to solve the problem above is to adopt a strongly-related concept as an alternative variable instead of language anxiety. Therefore, the present study employs willingness to communicate (WTC). WTC was first researched in the academic field of L1 communication (McCroskey \& Richmond, 1987, 1991), followed by L2 studies for the past decades (Clément, Baker, \& MacIntyre, 2003; MacIntyre, Baker, Clément, \& Conrod, 2001; MacIntyre \& Charos, 1996; MacIntyre, Clément, Dörnyei, \& Noels, 1998). MacIntyre et al. (1998) defined WTC as "readiness to enter into discourse at a particular time with a specific person or persons, using a L2" (p. 547) and suggested the multilayered pyramid model which has been oft-cited to date. The most important feature shown in this model is that WTC can be affected by various personal and social factors.

One of the most influential factors on WTC is language anxiety, the effects of which have been discussed at length. Many previous studies have adopted language anxiety as a predictor variable to ascertain negative impacts on WTC as an outcome variable (Clément, Baker, \& MacIntyre, 2003; Liu \& Jackson, 2008; MacIntyre \& Charos, 1996; Sugawara et al., 2013). In other words, as learners' language anxiety decreases, their WTC is encouraged more strongly. According to those findings, the following hypothesis would be formed. If coping strategies successfully reduce language anxiety, a higher (or lower) frequency of coping strategy use will decrease (or increase) language anxiety (arrow 1 in Figure 1) and, as a result, WTC will be encouraged (or dampened; arrow 2). Thus, the higher (or lower) frequency of use of coping strategies results in more encouraged (or dampened) WTC (arrow 3). Therefore, while the effects of coping strategies on language anxiety cannot be directly investigated (dashed arrow 1), they could be 
demonstrated indirectly in the relationships between coping strategies and WTC (solid arrow 3), because, as mentioned above, language anxiety should have a negative impact on WTC (solid arrow 2).

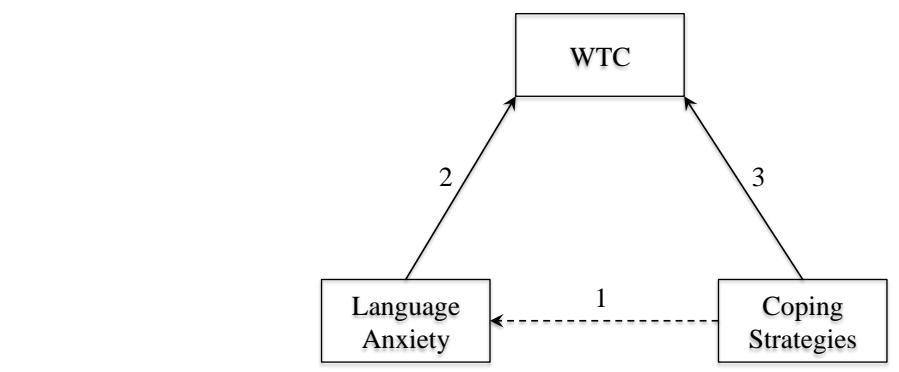

Figure 1. Effects of coping strategies on language anxiety represented by employing the concept of WTC.

\section{E. Classroom Speaking Anxiety of Japanese EFL Learners}

For the purpose of the investigation stated above, the present study focuses particularly on the classroom speaking anxiety of Japanese EFL learners. As explained, because language anxiety is essentially defined as a situation-specific concept, the way it emerges depends on each situational factor. First of all, this study aims to highlight Japanese EFL learners' classroom situations, where they would have the greatest opportunity to use English in their EFL setting. Another important factor is language modality (i.e., speaking, listening, reading, or writing). Since academic research in language anxiety became prevalent, many findings have indicated that among the four basic modalities, speaking is the most closely related to anxiety (e.g., Horwitz, et al., 1986; Young, 1990). Recently, English education in Japan has begun to benefit from the communicative approach and encourages speaking activities in classroom situations. Unfortunately, however, many Japanese EFL learners in general have become reluctant to use English in speaking activities due to language anxiety. Thus, focusing on the speaking modality is believed to be the most valid option regarding this study on Japanese EFL learners.

\section{F. Research Questions}

This study aims to explore the effects of coping strategies on language anxiety, focusing on the relationships between coping strategies and WTC. The two target scopes are Japanese EFL learners and the speaking modality. More specifically, the following research questions are investigated.

1. Are there correlations between language anxiety and coping strategies? This study hypothesizes that there are no significant correlations, because the correlation coefficients reflect the issues of directionality stated in section I-C.

2. Are there correlations between language anxiety and WTC, and does the former successfully predict the latter? This study hypothesizes that there are significant negative correlations and the former successfully predicts the latter in a negative way, based on many previous studies.

3. Are there correlations between coping strategies and WTC, and does the former successfully predict the latter? This study hypothesizes that there are significant positive correlations and the former successfully predicts the latter in a positive way. If the results successfully verify hypothesis 1 and 2, and ensure the positive evidence for hypothesis 3 , significant effects of coping strategies on language anxiety will be indirectly represented in the relationships between coping strategies and WTC.

4. If the research verifies all the hypotheses above, which coping strategies are more effective?

\section{METHOD}

\section{A. Participants}

The participants in this study consisted of 194 Japanese EFL undergraduate learners in the vicinity of the Greater Tokyo Area. Removing 36 cases in which one or more mistakes were made in the responses to the questionnaire survey (see the instruments below), 158 (male $=140$, female $=18$ ) eligible cases were analyzed. The first language of every participant was Japanese; in addition, none had ever been out of Japan for more than three months. All were participating in English compulsory classes twice a week (90 minutes per class), and had almost the same amount of homework every week, typically requiring approximately an hour per assignment for each class. The number of male students was considerably higher than that of female students, because the study took place in the department of science-related majors, where male students are commonly predominant in Japan. There were 72 first-year, 85 second-year and one third-year students. Their scores from the Test of English for International Communication (TOEIC) Listening \& Reading were in the range of 300 to $400 .{ }^{1}$ Judging from the conversion table between TOEIC Listening \& Reading scores and the Common European Framework of Reference for Languages (CEFR), their English

\footnotetext{
1 The TOEIC is "an English language proficiency test for people whose native language is not English. It measures the everyday English skills of people working in an international environment" (Educational Testing Service, 2013, p. 2).
} 
proficiency levels were converted primarily to level A2 in the CEFR (Eigo yon ginou shikaku kentei shiken kondan-kai, 2017).

\section{B. Instruments}

This study adopted the following questionnaires. If the original scale did not have a Japanese version, it was translated into Japanese. Furthermore, the wording of certain question items was altered to focus on speaking activities in classroom situations. To ensure the translation accuracy and content validity of each questionnaire, the researchers consulted with a professor, English teachers, and graduate students who majored in applied linguistics and English education. Appendix A, B, and C correspond to the following three questionnaires, respectively. The Japanese sentences in each Appendix reflect the final version of question items that we developed and to which the participants actually responded. Each Japanese sentence was translated into English and shown in each Appendix for the benefit of international readers of this article.

\section{Coping strategy for language anxiety}

As mentioned above, academic research should focus on realistic coping strategies which learners could use in actual learning situations. Therefore, a new questionnaire scale was developed focusing on speaking activities in classroom situations, based on the results of Kondo and Yang (2004). They suggested five categories of coping strategies for language anxiety that Japanese EFL learners had actually used in their English classrooms. The questionnaire allocated one representative question item on each category (Appendix A). Participants responded to each question item using a 6-point Likert scale $(1=$ strongly disagree, $2=$ disagree, $3=$ slightly disagree, $4=$ slightly agree, $5=$ agree, $6=$ strongly agree). This scale could work as a preliminary short version of Marwan's (2007) questionnaire, which helps to reduce pressure upon participants to respond.

\section{Language anxiety}

The eight items of the Foreign Language Classroom Anxiety (FLCA; Dewaele \& MacIntyre, 2014) scale were translated into Japanese. In addition, some words and phrases were modified focusing on speaking activities in classroom situations (Appendix B). In the original version, Dewaele and MacIntyre (2014) reported good internal consistency (Cronbach's $\alpha=.86)$. Participants responded to each question item using a 6-point Likert scale $(1=$ strongly disagree, $2=$ disagree, $3=$ slightly disagree, $4=$ slightly agree, $5=$ agree, $6=$ strongly agree ).

3. WTC

To measure WTC for speaking activities in classroom situations, this study adopted 16 question items for speaking situations/tasks included in Weaver's (2010) L2 WTC Questionnaire, which was originally developed by Weaver (2005) based on the dataset of Japanese EFL learners. This study modified the Japanese translation provided by Weaver (2010) to create a more comprehensible version (Appendix C). Participants responded to each question item by using a 6-point Likert scale $(1=$ definitely not willing, $2=$ not willing, $3=$ probably not willing, $4=$ probably willing, $5=$ willing, $6=$ definitely willing).

\section{Background information}

Five background question items were used to ascertain the following information: (1) gender, (2) major, (3) academic year, (4) first language, and (5) whether they have overseas experience exceeding three months.

\section{Procedures}

The participants were asked to respond to each item on the questionnaires in their English classes. The students were given ample time to finish the questionnaires, including allocated time for an explanation of how to complete the forms.

\section{Analytic Procedures}

In this study, each combination of two constructs was investigated. The first combination focused on coping strategies and language anxiety for the research question 1. As stated in section I-C, because the present study did not distinguish the direction (A) from (B) methodologically, it remained unclear which one was the predictor or the outcome variable. Thus, correlational analysis was used. The second combination was language anxiety and WTC for the research question 2. Since language anxiety predicts theoretically the extent of WTC (e.g., MacIntyre \& Charos, 1996), regression analysis, after calculating the correlation coefficient, was conducted with language anxiety as a predictor variable and WTC as an outcome variable. The third combination was coping strategies and WTC for the research questions 3 and 4. As language anxiety theoretically predicts WTC (e.g., MacIntyre \& Charos, 1996), coping strategies for language anxiety could also predict WTC. In other words, regarding the relationship between coping strategies and WTC, the following path could be assumed: coping strategies reduce speaking anxiety in classroom situations, and the reduced anxiety subsequently raises the level of WTC in speaking activities. Thus, this path could allow us to use coping strategies as predictor variables and WTC as an outcome variable. After calculating the correlation coefficients, multiple regression analysis was conducted.

\section{RESULTS}

\section{A. Excluding Outliers and Inappropriate Variables}

The preliminary analysis removed 9 multivariate outliers based on Mahalanobis distance. The subsequent statistical 
analyses were conducted with the remaining 149 cases. According to Cronbach's $\alpha$ of the FLCA, when "I always feel that the other students speak English better than I do" is excluded, the value will be raised from $\alpha=.78$ to $\alpha=.82$. Further, as for coping strategies, if "[w]hen I feel anxious about speaking in English in my class, I sometimes give up keeping up with the class" is excluded, the value will increase from $\alpha=.60$ to $\alpha=.72$. While the other four coping strategies represent learners' cognitive and behavioral efforts, this strategy allows them to avoid facing problems in language learning. In that sense, it has an obviously different nature from the others, which would be represented in the low Cronbach's $\alpha$. In addition, it is not necessarily appropriate to encourage learners to give up their learning processes. As a result, those two items were excluded from the subsequent analysis.

\section{B. Descriptive Statistics}

Table I shows descriptive statistics. All the variables were normally distributed according to Kunnan (1998). ${ }^{2}$

TABLE I.

\begin{tabular}{|c|c|c|c|c|c|c|c|}
\hline \multicolumn{8}{|c|}{ DESCRIPTIVE STATISTICS } \\
\hline & & & & $\mathrm{SE}$ & & $\mathrm{SE}$ & Cronbach's $\alpha$ \\
\hline Preparation & 3.36 & 1.32 & 0.07 & .20 & -0.51 & .40 & .72 \\
\hline Positive thinking & 2.52 & 1.31 & 0.65 & .20 & -0.27 & .40 & \\
\hline Peer seeking & 2.34 & 1.43 & 0.83 & .20 & -0.25 & .40 & \\
\hline Language anxiety & 4.22 & 0.96 & -0.33 & .20 & -0.26 & .40 & .82 \\
\hline
\end{tabular}

\section{Correlation Analysis}

Spearman's rank order correlations were calculated between each variable (Table II). The results did not show any significant correlations between language anxiety and coping strategies. On the other hand, there was a negative correlation between language anxiety and WTC $(p<.05)$. Furthermore, all coping strategies correlated positively with WTC $(p<.01)$.

TABLE II

CORRELATION MATRIX

\begin{tabular}{|c|c|c|c|}
\hline & Language anxiety & WTC & \\
\hline Preparation & .07 & .40 & $* *$ \\
\hline Relaxation & .15 & .21 & $* *$ \\
\hline Positive thinking & .03 & .22 & $* *$ \\
\hline Peer seeking & .12 & .27 & $* *$ \\
\hline Language anxiety & 1 & -.20 & $*$ \\
\hline WTC & & 1 & \\
\hline
\end{tabular}

\section{Regression Analysis}

As Table II shows, the correlation coefficients between language anxiety and WTC, and between coping strategies and WTC, were statistically significant. Then, simple regression analysis was conducted to investigate the predictive impact of language anxiety on WTC, and multiple regression analysis was also implemented to explore predictive impacts of coping strategies on WTC. The latter exploited the stepwise method to extract some coping strategies that significantly predict the extent of WTC. Some assumptions for regression analysis were confirmed in advance. First, as Porte (2002) recommends having 30 participants per predictor variable, a total of 149 cases in this study was deemed sufficient to meet the criteria. Second, according to Field (2009), there was no serious violation in the assumptions of multicollinearity, homoscedasticity of the residuals, independent errors of the residuals, normally distributed errors, and linearity between predictor and outcome variables. Table III shows the results of simple regression analysis. The beta value means that language anxiety significantly predicted WTC in a negative manner $(p<.01)$, and the adjusted $R^{2}$ accounted for $4 \%$ of the variance in WTC with small effect size (Mizumoto \& Takeuchi, 2008). Further, Table IV shows the results of multiple regression analysis. The stepwise method regarded two predictor variables as statistically significant (preparation, $p<.01$; positive thinking, $p<.05$ ), and the adjusted $R^{2}$ accounted for $15 \%$ of the variance in WTC with medium effect size (Mizumoto \& Takeuchi, 2008).

\footnotetext{
${ }^{2}$ Kunnan (1998) stated, "[i]f values for kurtosis or skewness of the individual variables of interest exceed \pm 2.0 , the data are not normally distributed" (p. 313).
} 
TABLE III

RESULTS OF SIMPLE REGRESSION ANALYSIS

\begin{tabular}{llrrr}
\hline Predictor variable & $B$ & $S E B$ & $\beta$ & \\
\hline Language anxiety & -0.22 & 0.08 & -.21 & $* *$ \\
\hline$* * p<.01$ & & & &
\end{tabular}

$R=.21, R^{2}=.05$, Adjusted $R^{2}=.04$

TABLE IV

RESULTS OF MULTIPLE REGRESSION ANALYSIS

\begin{tabular}{lcccl}
\multicolumn{7}{c}{ RESULTS OF MULTIPLE REGRESSION ANALYSIS } \\
\hline Predictor variable & $B$ & SEB & $\beta$ & \\
\hline Preparation & 0.24 & 0.06 & .33 & $* *$ \\
Positive thinking & 0.12 & 0.06 & .16 & $*$ \\
\hline$* p<.05 ; * *<.01$ & & & &
\end{tabular}

${ }^{*} p<.05 ; * * p<.01$

$R=.40, R^{2}=.16$, Adjusted $R^{2}=.15$

\section{DiscUSSION}

\section{A. Research Question 1}

As the dataset in this study, stated in section I-C, did not distinguish the difference between the direction (A) and (B), the research question 1 hypothesized no significant correlations. In fact, the results did not show significant correlations between any of the coping strategies and language anxiety (Table II). Thus, it indicates that correlational analysis would not help to identify the exact effects of coping strategies on language anxiety.

\section{B. Research Question 2}

There was a negative correlation found between language anxiety and WTC $\left(r_{s}=-.20, p<.05\right)$. Sugawara et al. (2013), focusing on Japanese EFL learners, also elicited a negative correlation between the two $(r=-.43, p<.01)$. Although the correlation found in this study is weaker, it has the similar feature to the previous empirical study in the same characteristics of target participants. Simple regression analysis conducted with language anxiety as a predictor variable and WTC as an outcome variable showed the similar results to previous studies (e.g., MacIntyre \& Charos, 1996). Therefore, language anxiety should be regarded as a powerful disincentive factor to learners' WTC.

\section{Research Questions 3 and 4}

All of the coping strategies correlated positively with WTC $(p<.01)$. These results show that the more (or less) learners use coping strategies, the higher (or lower) their WTC becomes. Then, referring to the assumption showed in Figure 1, multiple regression analysis was conducted between coping strategies and WTC to investigate indirectly the effects of coping strategies on language anxiety.

The analysis with the stepwise method extracted two significantly effective coping strategies that showed positive predictive impacts on WTC. This result represents the positive effects of preparation (i.e., To reduce anxiety about speaking in English in my class, I study hard and prepare well in advance.) and positive thinking (i.e., To reduce anxiety about speaking in English in my class, I tell myself that I can do it.) on language anxiety.

The final part of the discussion supports the effects of preparation and positive thinking based on some theoretical findings. Language anxiety inside classrooms can be affected by various factors. Young (1991) classified potential sources of language anxiety into six types: personal and interpersonal anxieties, learner beliefs about language learning, instructor beliefs about language teaching, instructor-learner interactions, classroom procedures, and language testing. Above all, personal and interpersonal anxieties have enjoyed the greatest focus in language anxiety research (Young, 1991), and Kitano (2001) emphasizes influences of self-perceived ability and fear of negative evaluation. More specifically, when learners have either lower confident in their own L2/FL abilities or greater fear of negative evaluation from others, or both, their language anxiety is more intensified. Preparation and positive thinking extracted in this study should be related to those two aspects. When learners "study hard and prepare well in advance," they feel more confident in their abilities and also feel less fear of negative evaluation as it reduces the potential danger of making mistakes in the classroom. Furthermore, when learners successfully "tell themselves that they can do it," they will enhance their self-perceived competence more directly, and they might not be so afraid of failure with greater belief in their capability of executing required actions.

Interestingly, there are no effects of relaxation and peer seeking on language anxiety. Based on speculative discussion, when participants responded to the question item of relaxation, they possibly assumed very simple and easy-to-master methods such as deep breathing, which might be shown in the relatively high frequency of the use of relaxation (Table I). Thus, introducing more psychologically sophisticated methods would dramatically enhance the effects of relaxation (e.g., progressive relaxation ${ }^{3}$ ). As for peer seeking, it would, theoretically, introduce some moderating effects on fear of negative evaluation from others. However, while both preparation and positive thinking aim at better performance in English speaking activities, learners might merely try to find "birds of a feather" in peer seeking. In that sense, it is no

\footnotetext{
${ }^{3}$ Progressive relaxation is "a technique in which the individual is trained to relax the entire body by becoming aware of tensions in various muscle groups and then relaxing one muscle group at a time" (VandenBos, 2009, p. 400).
} 
surprise that the former two strategies are more effective than the latter. In any case, it is certain that further investigation is needed.

\section{Pedagogical Implications}

One of the most important aspects is that learners can use the coping strategies independently to raise their autonomy in language learning. However, because learner autonomy is "not simply a matter of placing learners in situations where they have to be independent" (Sinclair, 2000, p. 8), proper support from others will still be required. As a result, this section discusses the kind of consideration teachers should take into encouraging learners to use the coping strategies of preparation and positive thinking.

The most crucial promoter for learners to achieve "studying hard and preparing well in advance (i.e., preparation)" is metacognition, or learners' objective perspective to control their own behavior and cognition. Metacognition has long been highlighted as an indispensable factor for learner autonomy in education and pedagogy including language learning. Sannomiya (2008) suggested a comprehensive theoretical categorization to sum up previous theories, and Yasuda (2016) developed a questionnaire scale to measure the metacognitive abilities of Japanese EFL learners based on the taxonomy. According to those findings, for effective preparation, learners need to obtain knowledge about learning strategies and their own characteristics as language learners and also carry out the cycle of learning processes (plan $\rightarrow$ action $\rightarrow$ evaluation) using this knowledge. Therefore, this implication suggests that teachers should let learners create their own learning portfolio. For example, teachers provide learners with a booklet-style portfolio where learners are able to write down their various language learning experiences such as learning plans, materials, strategies, and logs. Then, learners should undergo a self-evaluation process and obtain feedback from teachers and peers. By using the portfolio, learners could exploit more effective materials and strategies to boost the plan $\rightarrow$ action $->$ evaluation cycle of their learning processes. As a result, they could successfully reduce their language anxiety and join the class more actively.

Second, while learners should try to use positive thinking by themselves, teachers' consideration still has a strong impact on the level of effective use of this strategy. This positive thinking strategy is similar to the concept of self-efficacy that has been well-researched in psychology. Bandura (1997) explained it as "beliefs in one's capabilities to organize and execute the courses of action required to produce given attainments" (p. 3). As one of the sources that lead people to self-efficacy, Bandura (1997) raised verbal persuasion. That is, if significant others (i.e., teachers) verbally express faith in learners' capabilities, it will be easier for learners to maintain their own self-efficacy. Therefore, when using the positive thinking strategy, while learners should convince themselves that they will surely be able to do it, teachers should also deliver the same persuasion, or "you can do it" sentiment, and encourage them to execute the action. Regardless of learners' own self-belief in their abilities, language anxiety would not be effectively reduced unless teachers sent the same, positive message. These consistent evaluations would lead learners to a more stable sense of self-competence.

\section{CONCLUSIONS AND FUTURE DIRECTIONS}

This study has demonstrated that preparation and positive thinking are effective coping strategies on language anxiety. The last section describes two fundamental points for future research.

First, longitudinal studies should be conducted to investigate the effects of coping strategies more authentically. For example, studies of a few months' length, at a minimum, should be conducted to train learners for coping strategies, observe their actual use, and measure the change of language anxiety. As preparation and positive thinking are seen as more effective in this study, the research could focus particularly on those two strategies. Then, it would be less likely to seriously impede participants' learning processes, even if the research could be conducted in actual classroom situations.

The second issue is related to trait anxiety. As already stated, anxiety has two types: state level as a transient experience of anxiety and trait level as an individual difference of the extent to which a person can be anxious. Learners with high trait anxiety would more easily feel anxious in a variety of situations. Besides, this personality factor might make learners feel language anxiety more suddenly, keenly, and strongly, where the effects of coping strategies indicated in this study would wane. For example, regardless of the level of preparation carried out for an English class in advance, the learner may experience the same (or greater) levels of anxiety. Further, they might not be easily persuaded when teachers and peers say, "you can do it." Therefore, further research is needed to investigate the effects of coping strategies for learners with high trait anxiety. If there are no effects found, other specific strategies should be considered for those learners. 


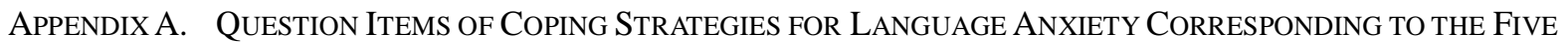
CATEGORIES IN KONDO AND YANG (2004)

\begin{tabular}{|c|c|}
\hline $\begin{array}{l}\text { Categories of coping } \\
\text { strategies in Kondo and } \\
\text { Yang }(2004)\end{array}$ & Question items \\
\hline \multirow{2}{*}{ 1. Preparation } & To reduce anxiety about speaking in English in my class, I study hard and prepare well in advance. \\
\hline & 私は、授業中英語で話すときの不安を減らすのに、事前の勉強や準備を一生懸命やるようにしている。 \\
\hline \multirow{2}{*}{ 2. Relaxation } & To reduce anxiety about speaking in English in my class, I try to relax. \\
\hline & 私は、授業中英語で話すときの不安を減らすのに、気持ちをリラックスさせるようにしている。 \\
\hline \multirow{2}{*}{ 3. Positive thinking } & To reduce anxiety about speaking in English in my class, I tell myself that I can do it. \\
\hline & 私は、授業中英語で話すときの不安を減らすのに、自分はできると思い込むようにしている。 \\
\hline \multirow[b]{2}{*}{ 4. Peer seeking } & To reduce anxiety about speaking in English in my class, I tell myself that the other students must also feel anxious. \\
\hline & $\begin{array}{l}\text { 私は、授業中英語で話すときの不安を減らすのに、他のクラスメイトも同じように不安を感じていると、 } \\
\text { 自分に言い聞かせるようにしている。 }\end{array}$ \\
\hline \multirow{2}{*}{ 5. Resignation } & When I feel anxious about speaking in English in my class, I sometimes give up trying to keep up with the class. \\
\hline & 私は、授業中英語で話すのに不安を感じるとき、授業についていくのをあきらめることがある。 \\
\hline
\end{tabular}

ApPendix B. Q Question Items of LANGuage AnXIETy Developed Based on DewaEle And MacIntyre (2014)

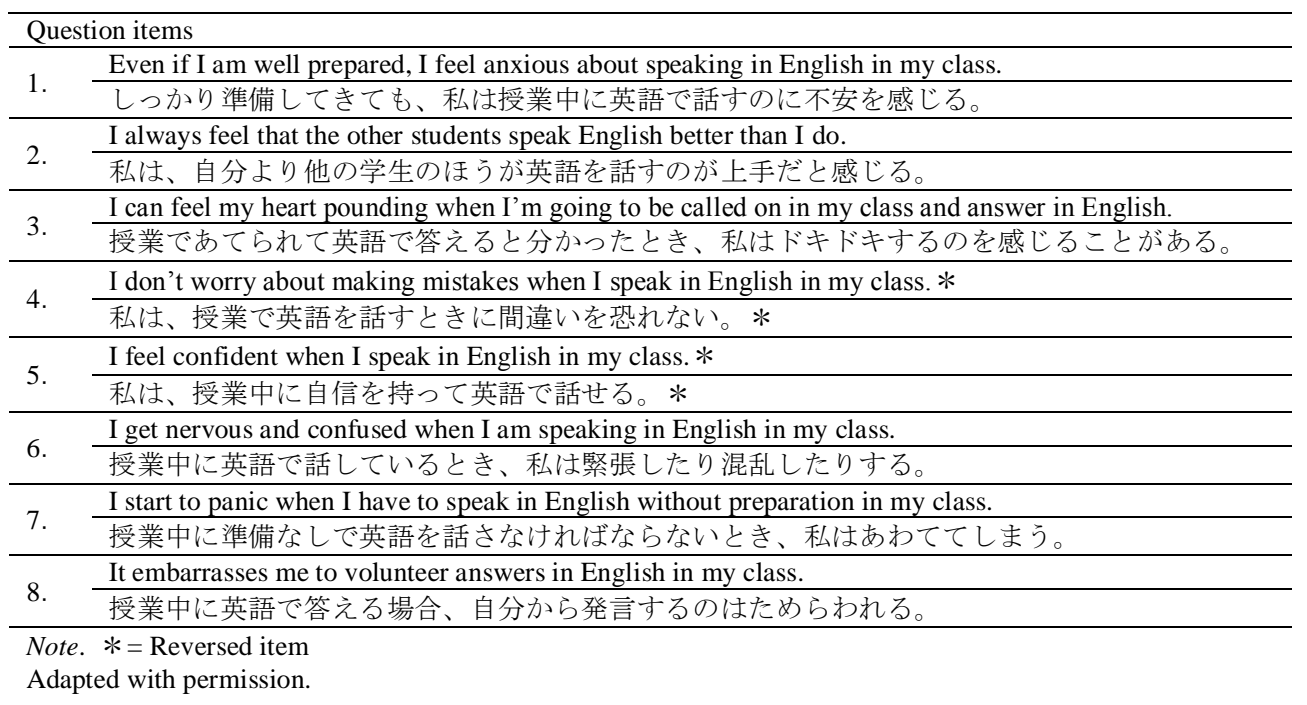

ApPENDix C. QUeSTiOn ItEMS OF WTC (WeAVER, 2010)

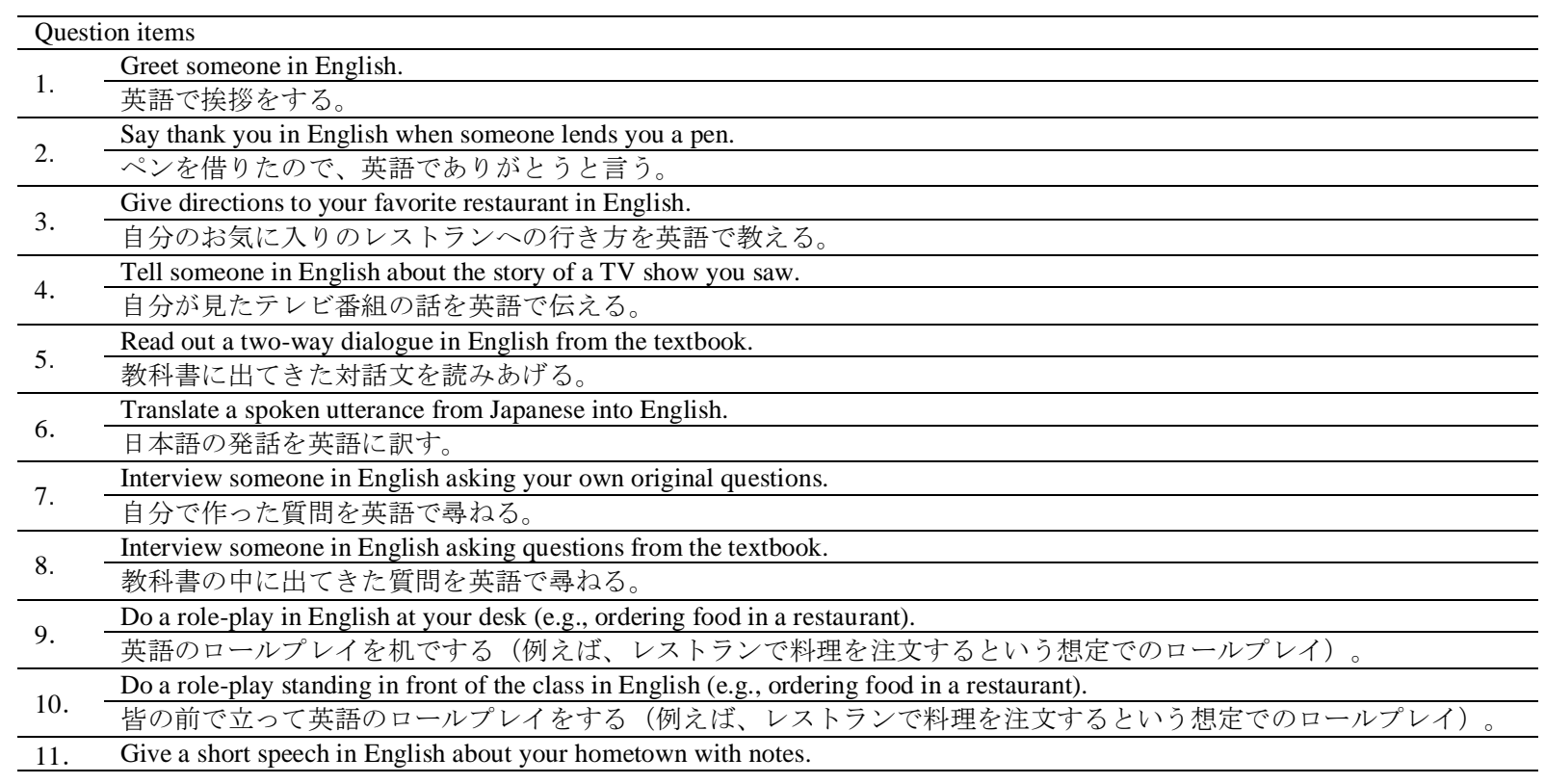




\begin{tabular}{|c|c|}
\hline & メモを見ながら、自分の出身地について短いスピーチを英語でする。 \\
\hline \multirow{2}{*}{12.} & Give a short self-introduction without notes in English. \\
\hline & 何も見ずに自己紹介を英語でする。 \\
\hline \multirow{2}{*}{13.} & Ask someone in English to repeat what they have just said in English because you didn't understand. \\
\hline & 何と言ったのか分からなかったので、もう一度言ってもらうように英語でお願いする。 \\
\hline \multirow{2}{*}{14.} & Ask the meaning of word you do not know in English. \\
\hline & 知らない英単語の意味を英語で尋ねる。 \\
\hline \multirow{2}{*}{15 . } & Ask someone how to pronounce a word in English. \\
\hline & 英単語の発音方法を英語で尋ねる。 \\
\hline \multirow{2}{*}{16.} & Ask someone in English how to say a phrase you know how to say in Japanese but not in English. \\
\hline & 日本語では知っている言い回しを英語では何というのか知らないので、英語で尋ねる。 \\
\hline
\end{tabular}

\section{ACKNOWLEDGEMENTS}

We would like to thank the participants who willingly answered the questionnaires and assisted with our data collection. We are grateful to Dr. Tetsuo Harada and our colleagues for their valuable feedback and advice on the research process. Lastly but most importantly, our deepest appreciation also goes to the editors and anonymous reviewers for their insightful feedback on this article.

\section{REFERENCES}

[1] Alrabai, F. (2015). The influence of teachers' anxiety-reducing strategies on learners' foreign language anxiety. Innovation in Language Learning and Teaching, 9(2), 163-190. doi:10.1080/17501229.2014.890203.

[2] Bandura, A. (1997). Self-efficacy: The exercise of control. New York, NY: W. H. Freeman.

[3] Benson, P. (1997). The philosophy and politics of learner autonomy. In P. Benson \& P. Voller (Eds.), Autonomy and independence in language learning (pp. 18-34). Harlow, UK: Addison Wesley Longman.

[4] Clément, R., Baker, S. C., \& MacIntyre, P. D. (2003). Willingness to communicate in a second language: The effects of context, norms, and vitality. Journal of Language and Social Psychology, 22(2), 190-209. doi:10.1177/0261927X03022002003.

[5] Dewaele, J.-M., \& MacIntyre, P. D. (2014). The two faces of Janus? Anxiety and enjoyment in the foreign language classroom. Studies in Second Language Learning and Teaching, 4(2), 237-274. doi:10.14746/ssllt.2014.4.2.5, licensed under Creative Commons Attribution 4.0 International Public License.

[6] Dörnyei, Z. (2005). The psychology of the language learner: Individual differences in second language acquisition. Mahwah, NJ: Lawrence Erlbaum Associates.

[7] Educational Testing Service. (2013). TOEIC user guide: Listening \& reading. Retrieved from https://www.ets.org/Media/Tests/Test_of_English_for_International_Communication/TOEIC_User_Gd.pdf (Last accessed 24 February 2018).

[8] Eigo yon ginou shikaku kentei shiken kondan-kai [Colloquium on the English Four Skills Qualification Examination] (2017). Eigo yon ginou shiken jouhou saito [English Four Skills Test Information Site]. Retrieved from http://4skills.jp/qualification/comparison_cefr.html (Last accessed 1 May 2018).

[9] Field, A. (2009). Discovering statistics using SPSS (3rd ed.). London, UK: Sage Publications.

[10] Hilleson, M. (1996). "I want to talk with them, but I don't want them to hear": An introspective study of second language anxiety in an English-medium school. In K. M. Bailey \& D. Nunan (Eds.), Voices from the language classroom (pp. 248-275). Cambridge, UK: Cambridge University Press.

[11] Horwitz, E. K. (2001). Language anxiety and achievement. Annual Review of Applied Linguistics, 21, 112-127. doi: $10.1017 / \mathrm{S} 0267190501000071$.

[12] Horwitz, E. K. (2010). Foreign and second language anxiety. Language Teaching, 43(2), $154-167$. doi: $10.1017 /$ S026144480999036X.

[13] Horwitz, E. K., Horwitz, M. B., \& Cope, J. (1986). Foreign language classroom anxiety. The Modern Language Journal, 70(2), 125-132. doi:10.1111/j.1540-4781.1986.tb05256.x.

[14] Kim, S. Y. (1998). Affective experiences of Korean college students in different instructional contexts: Anxiety and motivation in reading and conversation courses (Doctoral dissertation). Retrieved from Linguistics and Language Behavior Abstracts. (9907536).

[15] Kitano, K. (2001). Anxiety in the college Japanese language classroom. The Modern Language Journal, 85(4), 549-566. doi: 10.1111/0026-7902.00125.

[16] Kondo, D. S., \& Yang, Y.-L. (2004). Strategies for coping with language anxiety: The case of students of English in Japan. ELT Journal, 58(3), 258-265. doi:10.1093/elt/58.3.258.

[17] Kunnan, A. J. (1998). An introduction to structural equation modelling for language assessment research. Language Testing, 15(3), 295-332. doi:10.1177/026553229801500302.

[18] Larsen-Freeman, D. (2000). Techniques and principles in language teaching. Oxford, UK: Oxford University Press.

[19] Liu, M., \& Jackson, J. (2008). An exploration of Chinese EFL learners' unwillingness to communicate and foreign language anxiety. The Modern Language Journal, 92(1), 71-86. doi:10.1111/j.1540-4781.2008.00687.x.

[20] MacIntyre, P. D. (1999). Language anxiety: A review of the research for language teachers. In D. J. Young (Ed.), Affect in foreign language and second language learning: A practical guide to creating a low-anxiety classroom atmosphere (pp. 24-45). Boston, MA: McGraw-Hill College.

[21] MacIntyre, P. D., Baker, S. C., Clément, R., \& Conrod, S. (2001). Willingness to communicate, social support, and language-learning orientations of immersion students. Studies in Second Language Acquisition, 23(3), 369-388. 
[22] MacIntyre, P. D., \& Charos, C. (1996). Personality, attitudes, and affect as predictors of second language communication. Journal of Language and Social Psychology, 15(1), 3-26. doi:10.1177/0261927X960151001.

[23] MacIntyre, P. D., Clément, R., Dörnyei, Z., \& Noels, K. A. (1998). Conceptualizing willingness to communicate in a L2: A situational model of L2 confidence and affiliation. The Modern Language Journal, 82(4), 545-562. doi: 10.1111/j.1540-4781.1998.tb05543.x.

[24] MacIntyre, P. D., \& Gardner, R. C. (1994). The subtle effects of language anxiety on cognitive processing in the second language. Language Learning, 44(2), 283-305. doi:10.1111/j.1467-1770.1994.tb01103.x.

[25] Marwan, A. (2007). Investigating students' foreign language anxiety. Malaysian Journal of ELT Research, 3, $37-55$.

[26] McCroskey, J. C., \& Richmond, V. P. (1987). Willingness to communicate. In J. C. McCroskey \& J. A. Daly (Eds.), Personality and interpersonal communication (pp. 129-156). Newbury Park, CA: Sage Publications.

[27] McCroskey, J. C., \& Richmond, V. P. (1991). Willingness to communicate: A cognitive view. In M. Booth-Butterfield (Ed.), Communication, cognition, and anxiety (pp. 19-37). Newbury Park, CA: Sage Publications.

[28] Mizumoto, A., \& Takeuchi, O. (2008). Basics and considerations for reporting effect sizes in research papers. Studies in English Language Teaching, 31, 57-66.

[29] Murase, F. (2015). Measuring language learner autonomy: Problems and possibilities. In C. Everhard \& L. Murphy (Eds.), Assessment and autonomy in language learning (pp. 35-63). Basingstoke, UK: Palgrave Macmillan.

[30] Oxford, R. L. (2003). Toward a more systematic model of L2 learner autonomy. In D. Palfreyman \& R. C. Smith (Eds.), Learner autonomy across cultures: Language education perspectives (pp. 75-91). Basingstoke, UK: Palgrave Macmillan.

[31] Pappamihiel, N. E. (2002). English as a second language students and English language anxiety: Issues in the mainstream classroom. Research in the Teaching of English, 36, 327-355.

[32] Porte, G. K. (2002). Appraising research in second language learning: A practical approach to critical analysis of quantitative research. Amsterdam, Netherlands: John Benjamins.

[33] Saito, Y., \& Samimy, K. K. (1996). Foreign language anxiety and language performance: A study of learner anxiety in beginning, intermediate, and advanced-level college students of Japanese. Foreign Language Annals, 29(2), 239-249. doi: 10.1111/j.1944-9720.1996.tb02330.x.

[34] Sannomiya, M. (2008). Metaninchi-kenkyu no haikei to igi [The backgrounds and purposes of research for metacognition]. In M. Sannomiya (Ed.), Meta-ninchi: Gakusyu wo sasaeru koji-ninchi-kinou [Metacognition: A higher cognitive function to support learning]. Kyoto, Japan: Kitaohji Shobo.

[35] Sinclair, B. (2000). Learner autonomy: The next phase? In B. Sinclair, I. McGrath, \& T. Lamb (Eds.), Learner autonomy, teacher autonomy: Future directions (pp. 4-14). Harlow, UK: Pearson Education.

[36] Sugawara, K., Sano, A., Kawai, Y., Yokoyama, Y., Nakamura, K., \& Mitsugi, M. (2013). Influences of international attitudes and possible selves on willingness to communicate in English: A comparative analysis of models for Japanese high school and university learners of English. JACET Journal, 57, 21-40.

[37] VandenBos, G. R. (Ed.). (2009). APA concise dictionary of psychology. Washington, DC: American Psychological Association.

[38] Weaver, C. (2005). Using the Rasch model to develop a measure of second language learners' willingness to communicate within a language classroom. Journal of Applied Measurement, 6, 396-415.

[39] Weaver, C. (2010). Japanese university students' willingness to use English with different interlocutors (Doctoral dissertation). Retrieved from ProQuest Dissertations and Theses Global. (305227822).

[40] Yasuda, T. (2016). A preliminary design of a metacognitive awareness inventory for Japanese learners of English. KATE Journal, 30, 57-70. doi:10.20806/katejournal.30.0_57.

[41] Young, D. J. (1990). An investigation of students' perspectives on anxiety and speaking. Foreign Language Annals, 23(6), 539-553. doi:10.1111/j.1944-9720.1990.tb00424.x.

[42] Young, D. J. (1991). Creating a low-anxiety classroom environment: What does language anxiety research suggest? The Modern Language Journal, 75(4), 426-439. doi:10.1111/j.1540-4781.1991.tb05378.x.

[43] Young, D. J. (Ed.). (1999). Affect in foreign language and second language learning: A practical guide to creating a low-anxiety classroom atmosphere. Boston, MA: McGraw-Hill College.

Toshinori Yasuda worked as a certified psychological counselor after receiving his first MA in psychology from Hokkaido University, Japan. Then, he received his second MA in English education from Waseda University and currently works as a research associate at Waseda University and an adjunct lecturer of English at Tokai University, Japan. His current academic interests focus on interdisciplinary research among applied linguistics, foreign/second language education, and psychology.

Lisa Nabei worked as a staff writer and underwriter at financial institutions after receiving BA in Human Geography from University of Nottingham. Then she received her MA in English education from Waseda University, and currently works as an Assistant Professor of International Education Centre at Tokai University in Tokyo, Japan. Her interest lies in second/foreign language acquisition, especially teaching English to the adults who are learning English in a non-English-speaking environment. 